\title{
Survey-based research on patients' knowledge about endodontic treatment
}

\begin{abstract}
Introduction. Patients' awareness and knowledge of the endodontic treatment is a very important issue in everyday practice of a dentist. It influences significantly the course and effects of treatment.

Aim. The paper presents an analysis of data collected from the patients about their concerns, expectations and perceptions about root canal treatment.

Material and methods. Questionnaire surveys were conducted in a group of 203 patients consisting questions characterizing their knowledge about endodontic treatment - their expectations, experiences, possible complications and treatment costs.

Results. Analyzing the experiences of patients regarding endodontic treatment, it was found that $69 \%$ of people in the past had experienced the procedure of root canal treatment. Most respondents define their state of knowledge of root canal treatment as an average. Fifty-seven percent of respondents admitted to knowing the price of endodontic treatment, $67 \%$ of them said that the cost was adequate to the complexity of the procedure. The study shows that most patients still choose specialists $(38 \%)$.
\end{abstract}

Conclusion. An improvement of knowledge and awareness of patients about the endodontic treatment has been observed.

Keywords: endodontic treatment, pain in dentistry, pro-health awareness.

DOI: $10.2478 /$ pjph-2014-0030

\section{INTRODUCTION}

The conviction of difficulties related to root canal treatment, including pain associated with it has been functioning among patients [1-6]. It raises many concerns, which often lead to cancelling the visits to the dental office. Many patients admit that they feel the stress related with the planned endodontic treatment. Publications on patients' awareness of this type of procedures are rarely presented. Contemporary endodontics is developing continuously. It concerns not only the instruments, but also the treatment procedures. The basic principle of modern endodontics is painlessness and effectiveness of the treatment. There are many methods providing the patient with comfort by reducing pain during treatment: local and conduction anesthesia, nitrous oxide or even general anesthesia.

In all professions based on the work with other people, understanding of motivational processes and skills of using knowledge is very important [7]. These factors are particularly important in everyday practice of a dentist. Properly conducted interview with the patient helps in deciding on the appropriate therapeutic treatment, especially with regard to endodontics, which often prevents tooth loss.

There are many scientific reports on the pro-health behaviors of patients concerning oral health and hygiene $[1,2,4,6,8,9]$. In the literature, there is little information about patients' awareness with regard to endodontic treatment; therefore, an attempt to analyze this problem has been undertaken.

\begin{abstract}
AIM
The study aimed to assess patients' personal experiences and knowledge of endodontic treatment. The criteria that guided the patients in taking the decision of dental treatment, including endodontic treatment, have been analyzed.
\end{abstract}

\section{MATERIAL AND METHODS}

Questionnaire surveys were conducted in a group of 203 patients of the Department of Conservative Dentistry with Endodontics, Medical University of Lublin. There was designed a multiple-choice questionnaire consisting of socio-demographic questions characterizing the situation of respondents, as well as their knowledge about endodontic treatment - their expectations, experiences, possible complications and treatment costs. The analysis was performed using methods of descriptive statistics. The obtained data are presented in tables. 


\section{RESULTS}

The study group comprised 203 subjects. Due to the transparency of data, the results were included in the percentage values approximated to the whole numbers. The study included patients aged 18-65 years including 126 women (62\%) and 77 men (38\%). Among the patients, 35\% had higher education, $56 \%$ - secondary, and $9 \%$ - primary education. People who were employed accounted for $47 \%$ of the respondents, $28 \%$ were students, $10 \%$ - pensioners, and $8 \%$ - unemployed.

When analyzing the experiences of patients regarding endodontic treatment, it was found that $69 \%$ of people in the past had experienced the procedure of root canal treatment. Among patients who had undergone endodontic treatment, $52 \%$ reported it positively, $34 \%$ - badly while for $14 \%-$ it did not matter. In the study group, $45 \%$ of people reported that the procedure was painful, $6 \%$ did not remember it, and $48 \%$ said they felt pain throughout its duration. These procedures were performed by experienced dentists in $62 \%$, and in $28 \%$ by dental students, and in $4 \%-$ by interns (Table 1 ).

TABLE 1. The patients' own experience regarding root canal treatment.

\begin{tabular}{lcc}
\hline \multicolumn{1}{c}{ Study group } & Response & $\%$ \\
\hline Have you been treated & Yes & $69 \%$ \\
\hline endodontically? & No & $31 \%$ \\
\hline \multirow{2}{*}{ How do you recall it? } & Well & $52 \%$ \\
\cline { 2 - 3 } & Badly & $34 \%$ \\
\hline \multirow{3}{*}{ Was it a painful treatment? } & Yot important & $14 \%$ \\
\cline { 2 - 3 } & No & $45 \%$ \\
\hline & I don't remember & $6 \%$ \\
\cline { 2 - 3 } Who performed the treatment? & Student & $28 \%$ \\
\cline { 2 - 3 } & An intern & $4 \%$ \\
\cline { 2 - 3 } & Experienced dentist & $62 \%$ \\
\hline
\end{tabular}

Respondents, when asked to identify symptoms that might indicate a need for endodontic intervention mostly mentioned severe spontaneous toothache $(59 \%)$ and the pain while biting (19\%). A smaller group of respondents drew attention to the toothache appearing during eating $(12 \%)$ and a clear discoloration of the tooth crown (8\%). Other symptoms suggesting the need for such a treatment were mentioned by only $2 \%$ of respondents (Table 2 ).

TABLE 2. The criteria of symptoms confirming the need for endodontic treatment reported by patients.

\begin{tabular}{lc}
\hline \hline \multicolumn{1}{c}{ Symptoms } & $\%$ \\
\hline Toothache during eating & $12 \%$ \\
\hline Toothache when biting & $19 \%$ \\
\hline Strong spontaneous toothache & $59 \%$ \\
\hline Pronounced discoloration of the tooth crown & $8 \%$ \\
\hline Other & $2 \%$ \\
\hline
\end{tabular}

Table 3 shows the behavior of patients in case of a sudden, severe toothache. The vast majority of patients $(60 \%)$ immediately after the first symptoms report to the dentist, and $40 \%$ of respondents admit to using the "home remedies" to combat ailments. Patients mention taking anti-inflammatory drugs, analgesics and antibiotics, as the most preferred method. Moreover, they declare the use of rinses, cold compresses, dressings (a gauze swab dripped with medicine solution), and even acupuncture.

TABLE 3. Assessment of patients' behavior in case of toothache.

\begin{tabular}{lc}
\hline \multicolumn{1}{c}{ Patients' behavior of in case of toothache } & $\%$ \\
\hline YES, I use home remedies to relieve toothache & $40 \%$ \\
\hline NO, I refer to the dentist & $60 \%$ \\
\hline
\end{tabular}

Most respondents define their state of knowledge of root canal treatment as an average. They are willing to learn the details of its course (33\%), they know a lot about it (26\%); $10 \%$ of respondents derive information primarily from friends and the media and $11 \%$ of respondents are not interested in the course of treatment, $20 \%$ report not having any knowledge about endodontic treatment (Table 4).

TABLE 4. Self-evaluation of patients' knowledge on the endodontic treatment.

\begin{tabular}{lc}
\hline \hline \multicolumn{1}{c}{ Patients' knowledge on endodontic treatment } & $\%$ \\
\hline I know a lot & $26 \%$ \\
\hline Average knowledge, I ask for details & $33 \%$ \\
\hline Average knowledge, I am not interested in the course & $11 \%$ \\
\hline I do not know anything & $20 \%$ \\
\hline Knowledge from media & $10 \%$ \\
\hline
\end{tabular}

Table 5 presents the results concerning patients' concerns associated with dental treatment. The vast majority of respondents indicate the stressors: pain associated with surgery $(44 \%)$ and the associated high costs $(42 \%)$. Fear is also raised by the possible complication of having to remove a tooth despite taken treatment (34\%) and the long duration of the visit $(25 \%)$. The respondents are concerned about penetration of irrigant beyond the root apex (10\%), about tool breakage in the root canal $(9 \%)$, and the need to carry out multiple X-ray images (3\%).

TABLE 5. Patients' concerns associated with the endodontic treatment.

\begin{tabular}{lc}
\hline \multicolumn{1}{c}{ Patients' knowledge on endodontic treatment } & $\%$ \\
\hline Pain & $44 \%$ \\
\hline The need to remove the tooth despite undertaken treatment & $34 \%$ \\
\hline Breaking the file in the root canal & $9 \%$ \\
\hline Penetration of irrigant beyond the apex & $10 \%$ \\
\hline Multiple X-ray/ RVG images & $3 \%$ \\
\hline High costs & $42 \%$ \\
\hline Burden & $23 \%$ \\
\hline Long treatment time & $25 \%$ \\
\hline Other & $3 \%$ \\
\hline
\end{tabular}


Fifty-seven percent of respondents admitted to knowing the price of endodontic treatment, $67 \%$ of them said that the cost was adequate to the complexity of the procedure. Despite that, up to $54 \%$ of patients mentioned selecting those dental offices, in which they could get a reimbursement for the procedures from the National Health Fund. The data are summarized in Table 6 .

TABLE 6. Own experiences of patients on endodontic treatment costs and the criteria for selecting dental office.

\begin{tabular}{lccc}
\hline \hline \multicolumn{1}{c}{ Relationship } & Yes & No & Not important \\
\hline & $\%$ & $\%$ & $\%$ \\
\hline $\begin{array}{l}\text { Do you know the price } \\
\text { of endodontic treatment? }\end{array}$ & $57 \%$ & $43 \%$ & - \\
\hline $\begin{array}{l}\text { Is it adequate to the complexity } \\
\text { of the dental treatment? }\end{array}$ & $67 \%$ & $33 \%$ & - \\
$\begin{array}{l}\text { Do you prefer treatment financed } \\
\text { by the National Health Fund? } \\
\text { if possible) }\end{array}$ & $54 \%$ & $22 \%$ & $24 \%$ \\
\hline
\end{tabular}

The high price beyond the patients' financial capabilities is an insurmountable barrier - the answer has been given by $65 \%$ of respondents. Only to $35 \%$ of respondents, it is not an obstacle. As many as $48 \%$ of people admit that the high price of the treatment discredits the therapy in general, $52 \%$ say that despite the high costs, they would take an attempt of endodontic treatment. More than $79 \%$ of the respondents strongly select the root canal treatment, and only $21 \%$ are considering extraction as the ultimate method (Table 7).

TABLE 7. Selection criteria between endodontic treatment and tooth extraction.

\begin{tabular}{lcc}
\hline \hline \multicolumn{1}{c}{ Relationship } & Yes & No \\
\hline $\begin{array}{l}\text { Might the price influence your decision } \\
\text { about not taking endodontic treatment? }\end{array}$ & $48 \%$ & $52 \%$ \\
\hline $\begin{array}{l}\text { Would you be willing to pay a high price to make } \\
\text { sure the proper treatment? }\end{array}$ & $65 \%$ & $35 \%$ \\
\hline $\begin{array}{l}\text { Would you take the decision of tooth extraction } \\
\text { rather than take endodontic treatment? }\end{array}$ & $21 \%$ & $79 \%$ \\
\hline
\end{tabular}

The criteria, which patients are guided by when choosing the person carrying out root canal treatment - students, trainees and qualified doctors- are shown in Table 8 . The study shows that most patients still choose specialists $(38 \%)$. The opinion of a doctor is also significant $-25 \%$ of respondents indicate a dentist recommended by friends. For $16 \%$ of respondents it does not matter who performs the procedure. The decision on treatment performed by dental students could be taken by $17 \%$ of the respondents and for $4 \%$ of respondents specialization of dentists is not important.

TABLE 8. The criteria for selecting the person for performing endodontic treatment.

\begin{tabular}{lc}
\hline \hline \multicolumn{1}{c}{ Person performing endodontic treatment } & $\%$ \\
\hline Student of dentistry & $17 \%$ \\
\hline Recommended doctor & $25 \%$ \\
\hline Doctor without specialization & $4 \%$ \\
\hline Specialist & $38 \%$ \\
\hline Not important & $16 \%$ \\
\hline
\end{tabular}

In the last part of the survey the respondents were asked about the most important criterion for selecting the place for the root canal treatment. More than half of the patients $(52 \%)$ responded that highly qualified medical staff was the most important. For $21 \%$ of respondents the cost-free treatment was decisive, and for $11 \%$ - the painless procedure. Quick and easy access and friendly service was appreciated by $6 \%$ of patients and moderate cost - by $5 \%$. Table 9 shows the results.

TABLE 9. The criteria for selecting dental office.

\begin{tabular}{|c|c|}
\hline Selection criterion & $\%$ \\
\hline Free of charge treatment & $21 \%$ \\
\hline Professional staff & $52 \%$ \\
\hline Reasonable price & $5 \%$ \\
\hline Painless treatment & $11 \%$ \\
\hline Friendly service & $5 \%$ \\
\hline Quick and easy access & $6 \%$ \\
\hline
\end{tabular}

\section{DISCUSSION}

In recent years, endodontics has been one of the fastest growing areas of dentistry. The use of modern tools, rubber dam, and the microscope in daily practice, significantly influence the quality and durability of treatment effects. Patients more often do not identify the endodontic treatment as the most unpleasant procedure. Pain associated with endodontic procedures, although still arousing the strongest emotions, is felt as moderate, rarely sharp. In addition, patients can benefit from many forms of local anesthesia, and the use of nitrous oxide, which according to recent reports, enhances the effect of their actions. Another form of premedication are preoperative intravenous sedatives and analgesics. In extreme cases, general anesthesia is the alternative [10]. A study conducted by Klages et al. demonstrates that patients visiting the dental office expect pain usually larger than that actually experiencing during treatment [5].

In our research, postponing of treatment in case of toothache is worrying. According to researchers conducted by Armfield [11,12], patients avoid visits to the dentist, due to fear. Most of the surveyed patients admit that in a situation of spontaneous ailments localized in the mouth, they immediately report to the doctor, and others use their own methods. Respondents most often opt for pain relievers, antiinflammatory drugs or even antibiotics. Also natural methods are popular among the respondents: rinsing the mouth with herbal infusions - with sage and chamomile and crunching of not blossomed, dried buds of clove trees, and the use of cold compresses. Patients also say that they choose willingly ready-made preparations or topically apply cotton swabs soaked in alcohol. The most controversial methods included application of cotton swabs soaked in acetone, keeping the cigarette smoke in the mouth, placing of ash from a burnt newspapers in the tooth lesion, rinsing the mouth with water, vinegar and baking soda. One of the patients suggested the use of acupuncture in relieving pain. Chinese natural medicine can complement conventional techniques. It was also used in the protocol of reducing the stress of dental visits and brought surprisingly good results. It has been suggested 
that the most appropriate puncture points are the ears, feet and hands [11]. Michalek-Sauberer et al. described in their work the application of these techniques [13]. However, due to the limited number of publications, such information requires additional research.

Costs associated with endodontic treatment are still debatable. Patients often stress that they are too high and the treatment should be financed by insurance benefits. Nevertheless, more than half of respondents is willing to pay a higher amount to avoid tooth loss, similarly as in the research of Bahadori et al. [14].

The knowledge of patients concerning endodontic treatment has increased significantly over the last years. It is not only due to school education, but also mainly due to mass media - television, the Internet, newspapers. Patients are aware of the opportunities offered by the modern clinics not just immediate relief from pain, but also carrying out of the treatment at the highest level and the necessary postoperative care - ensuring long-term radiological surveillance allowing observation of results achieved and enabling immediate intervention in case of exacerbation of symptoms, and monitoring the effects of treatment $[15,16]$.

\section{CONCLUSIONS}

1. An improvement of knowledge and awareness of patients about the endodontic treatment has been observed.

2. The majority of patients surveyed are aware of the opportunities, which they may use during the course of endodontic treatment: different forms of anesthesia, root canal treatment modern techniques and treatment outcome prediction.

\section{REFERENCES}

1. Hamedy R, Shakiba B, Fayazi S, et al. Patient-centered endodontic outcomes, a Narrative Review. Iran Endod J. 2013;8(4):197-204.

2. Pak JG, White SN. Pain prevalence and severity before, during, and after root canal treatment: a systematic review. J Endod. 2011;37(4):429-38.

3. Georgelin-Gurgel M, Diemer F, Nicolas E, et al. Surgical and nonsurgical endodontic treatment-induced stress. J Endod. 2009;35(1):19-22.

4. Bracha HS, Vega EM, Vega CB. Posttraumatic dental-care anxiety (PTDA): Is dental phobia a misnomer? Hawaii Dent J. 2006;37(5):17-9.

5. Klages U, Ulusoy Ö, Kianifard S, et al. Dental trait anxiety and pain sensitivity as predictors of expected and experienced pain in stressful dental procedures. Eur J Oral Sci. 2004; 112(6): 477-83.

6. Olszewska-Czyż I, Domiszewska D, Pasierb L, et al. Analiza zachowań prozdrowotnych oraz samooceny zdrowia i higieny jamy ustnej pacjentów dorosłych $\mathrm{w}$ aspekcie lęku stomatologicznego oraz determinant socjodemograficznych. Mag Stomatol. 2013;23(12):129-136.

7. Oboda M. Wiedza na temat procesu motywacji pacjenta narzędziem pracy lekarza. E-Dentico. 2011;31(3):98-101.

8. Nakonieczna-Rudnicka M, Gogacz M, Makara-Studzińska M. Wpływ mediów na kształtowanie świadomości prozdrowotnej dotyczącej zdrowia jamy ustnej. Mag Stomatol. 2013;23(11):152-5.

9. Podsiadła-Urban G, Cieszko-Buk M, Bachanek T. Ocena zdrowia jamy ustnej u pacjentów reprezentujących pro- lub anty- zdrowotne style życia. Zdr Publ. 2012;122(2):165-70.

10. Montagnese TA. Why intravenous moderate sedation should be taught in graduate endodontic programs. J Dent Educat. 2012;76(3):288-290.

11. Armfield JM. What goes around comes around: revisiting the hypothesized vicious cycle of dental fear and avoidance. Community Dent Oral Epidemiol. 2013;41(3):279-287.

12. Armfield JM, Heaton L. Management of fear and anxiety in the dental clinic: a review. Austral Dent J. 2013;58(4):390-407.

13. Michalek-Sauberer A, Gusenleitner E, Gleiss A, et al.Auricular acupuncture effectively reduces state anxiety before dental treatment a randomised controlled trial. Clin Oral Investig. 2012;16(6):1517-22.

14. Bahadori M, Ravangard R, Asghari B. Perceived barriers affecting Access to preventive dental services: application of DEMATEL Method. Iran Red Crescent Med J. 2013;15(8):655-62.

15. Parirokh M, Abbott P. Various strategies for pain-free root canal treatment. Iran Endod J. 2014;9(1):1-14

16. Murray CA, Saunders WP. Root canal treatment and general health: a review of the literature. Inter End J. 2000;33(1):1-18.

\section{Corresponding author}

Renata Chałas

Chair and Department of Conservative Dentistry and Endodontics

Medical University of Lublin

7 Karmelicka Str., 20-081 Lublin, Poland

tel: +48 81 528-79-20

E-mail: renata.chalas@gmail.com 